\title{
Perspectivas da fraternidade na nova lei de migrações brasileira (Lei No 13.445/2017)
}

Perspectives of fraternity in Brasilian new Migration Law (law 13.445/2017)

\author{
Bárbara Bruna de Oliveira Simões ${ }^{1}$ \\ SANDRA REgina MARTINI ${ }^{2}$ \\ Centro Universitário Ritter dos Reis, Brasil
}

\begin{abstract}
RESUMO O presente trabalho trata da Nova Lei de Migrações brasileira -Lei $\mathrm{N}^{\circ}$ 13.445, de 24 de maio de 2017-, tendo como aporte a Metateoria do Direito Fraterno, de Eligio Resta, referencial teórico escolhido por analisar, de forma transdisciplinar, o direito. Nesse sentido, questiona-se como se apresentam os dispositivos da Nova Lei, sob o viés da fraternidade e objetiva-se realizar a intersecção entre a Nova Lei e o Direito Fraterno. O trabalho justifica-se pelas intensas migrações na atualidade, com características diversas que ensejam novos estudos na seara dos fluxos migratórios. No Brasil, a publicação da Nova Lei de Migrações significa inovação na política migratória, com reconhecimento de direitos e deveres iguais a brasileiros e migrantes. Este estudo desenvolvese pelo método dedutivo, partindo de aspectos gerais do Direito Fraterno e das migrações, para chegar à legislação migratória brasileira e, em especial, à Nova Lei. Utiliza-se, para isso, pesquisa bibliográfica e documental. Os resultados aqui apresentados objetivam criar novas discussões para que futuros estudos das migrações possam ser embasados pela ideia da fraternidade e possibilitem projetos práticos para a integração dos migrantes.
\end{abstract}

1. Mestranda em Direitos Humanos pelo Centro Universitário Ritter dos Reis Laureate International Universities/RS. Bolsista Capes. Advogada voluntária do Grupo de Assessoria a migrantes e refugiados da UFRGS (GAIRE). Email: barbarabsimoes@gmail.com.

2. Coordenadora e Professora do Mestrado em Direitos Humanos do Centro Universitário Ritter dos Reis Laureate International Universities. Professora Visitante do PPGD da UFRGS. Pós-doutorado em Direito (Roma Tre, 2006) e em Políticas Públicas (Universidade de Salerno, 2010). Pesquisadora Produtividade 2 CNPq. E-mail: srmatini@terra.com.br. 
PALAVRAS-CHAVE Migração, fraternidade, legislação, Brasil, metateoria do direito fraterno.

ABSTRACT It deals with the New Brazilian Migration Law, Law 13.445, May 24, 2017, by the contribution of the Metatheory or Fraternal Law, by Eligio Resta, a theoretical reference chosen for transdisciplinary analysis of law. It is questioned how the devices of the New Law are presented, under the bias of the fraternity. It aims to realize the intersection between the New Law and the Fraternal Law. The work is justified by the intense migrations of the present time, with diverse characteristics that provoke new studies in the area of the migratory flows. In Brazil, the publication of the New Migration Law means innovation in migration policy, with recognition of rights and duties equal to Brazilians and migrants. The study is developed by the deductive method, starting from the general aspects of the Fraternal Law and the migrations, to arrive at the Brazilian migratory legislation and, in particular, the New Law. Bibliographic and documentary research is used. The results presented here aim to create new discussions so that future studies of migrations can be based on the idea of fraternity and enable practical projects for the integration of migrants.

KEYWORDS Migration, fraternity, legislation, Brazil, metatheory of fraternal law.

\section{Introdução}

"A fraternidade, então, não é outra coisa em relação à lei, nem assume a aparência de outro direito, mas talvez seja seu coração secreto, quanto mais central, mais problemas são as dimensões planetárias.”

A fraternidade, embora presente na sociedade atual, apresenta-se, muito mais, pela sua negação do que pela sua efetivação. O coração "secreto" da nova Lei de Migrações é o tema desta reflexão, buscando encontrar os espaços possíveis, ainda que paradoxais, da própria inovação legislativa. A importância e o sentido de uma Lei estão na sua efetivação, não apenas na sua declaração ou positivação. Assim, o presente artigo apresenta a Nova Lei de Migrações brasileira -Lei n 13.445, de 24 de maio de 2017- e a fraternidade, tendo como aporte a Metateoria do Direito Fraterno, desenvolvida por

3. RESTA (2005) p.vi, tradução nossa. "La fraternità allora non é altra cosa rispetto al diritto, né assume le vesti di un altro diritto, ma ne è forse il cuore segreto, tanto più centrale quanto più soluzione dei problemi appare legata a dimensioni planetarie". 
Eligio Resta (2005). Questiona-se como são apresentados os dispositivos da Nova Lei de Migrações e quais as relações com a temática da fraternidade. Objetiva-se, com esse estudo, realizar uma intersecção entre os fluxos migratórios e a Teoria Direito Fraterno ${ }^{4}$.

O presente trabalho justifica-se pelos constantes fluxos migratórios visualizados ao longo do ano de 2017,,$^{5}$ que revelam novas características das migrações e, consequentemente, novas causas que levam ao deslocamento de pessoas, mudanças que ensejam novas formas de se estudar a temática dos fluxos migratórios. Sendo assim, o referencial teórico utilizado para o desenvolvimento dessa pesquisa é a Metateoria do Direito Fraterno ${ }^{6}$, de Eligio Resta ${ }^{7}$, que busca essas novas formas de enxergar o direito, pela transdisciplinaridade. O Direito Fraterno ${ }^{8}$ desafia e, ao mesmo tempo, integra outras teorias para demonstrar que é preciso resgatar velhos conceitos para entender a complexidade da sociedade cosmopolita. A teoria propõe observar o reconhecimento do "outro" e do "eu" como forma de integrar as diferenças, visando não eliminá-las, mas fazer com que as diferenças se apresentem como ponto de encontro entre realidades, culturas e povos.

Comprova-se, assim, a importância de sua abordagem para o estudo da Nova Lei de Migrações, uma vez que a mesma surge como uma oportunidade de promoção dos direitos humanos, revogando o Estatuto do Estrangeiro, legislação publicada em meio à ditadura militar brasileira, na qual a entrada de migrantes era pautada pelo viés da segurança nacional. A Nova Lei de Migrações apresenta direitos e deveres iguais a brasileiros e migrantes, pois todos pertencem à mesma humanidade. Dessa forma, para a adequada compreensão do assunto, o estudo desenvolve-se pelo método dedutivo, partindo dos aspectos gerais do Direito Fraterno e das migrações, para chegar à

4. Diante dessas preocupações, esta pesquisa se desenvolve no âmbito dos direitos humanos, tema no qual as autoras já possuem contato, por meio de projetos propostos no curso de Mestrado em Direitos Humanos, do qual fazem parte.

5. Para mais informações sobre os números referentes aos fluxos migratórios, ver ACNUR (2018) e MINISTÉRIO DA JUSTIÇA (2018).

6. Trabalha-se com essa vertente, mas não se desconsideram as contribuições de outros autores, como, por exemplo, Antonio Baggio, Angel Puyol, Paulo Ferreira da Cunha e Stefano Rodotà. Embora suas linhas teóricas não sejam aprofundadas na presente pesquisa, serão utilizadas inicialmente para que se compreenda o conceito de fraternidade ao longo da história e as diferenciações no seu sentido até o seu retorno anacrônico na atualidade.

7. Eligio Resta é professor e pesquisador italiano. Ministrou aulas na Faculdade de Direito da Università Roma Tre, na Itália. Dentre suas obras pode-se citar: La certeza y la esperanza (1996); Il diritto fraterno (2008), este com tradução para o português pela Editora da Unisc em 2004; Diritto vivente (2008).

8. A pesquisa embasa-se na Metateoria do Direito Fraterno, assim, quando se menciona somente Direito Fraterno, está sendo feita a análise da teoria. 
legislação migratória brasileira e, em especial, à Nova Lei. Utiliza-se pesquisa bibliográfica e documental em artigos e doutrinas nacionais e estrangeiras e em relatórios de organizações internacionais, como as Nações Unidas e o seu Alto Comissariado para Refugiados (ACNUR).

$\mathrm{O}$ artigo divide-se em quatro tópicos. No primeiro, apresenta-se a Metateoria do Direito Fraterno. No segundo, evidencia-se a intersecção entra a fraternidade e os fluxos migratórios, com os principais conceitos das migrações. No terceiro tópico, aborda-se a temática das migrações nas legislações brasileiras, partindo do Estatuto do Estrangeiro, que é a legislação anterior à Nova Lei de Migrações e, por fim, no último tópico, faz-se a relação entre os pressupostos da Metateoria do Direito Fraterno e os dispositivos da Nova Lei. As aproximações aqui realizadas objetivam criar discussões e novas visões, para que futuros estudos acerca das migrações possam ser embasados pela ideia da fraternidade e possibilitem projetos práticos para a integração dos migrantes.

\section{A metateoria do direito fraterno: limites e possibilidades da fraternidade}

"[...] os Direitos Humanos são aqueles direitos que somente podem ser ameaçados pela própria humanidade, mas que não podem encontrar vigor, também aqui, senão graças à própria humanidade."

Tratar de direitos humanos é identificar a sua paradoxalidade (função da teoria do direito fraterno: desvelar paradoxos), como o fato de que o reconhecimento pelos Direitos Humanos se dá, em grande parte, pela sua negação. No entanto, é somente na sociedade que podemos respeitar ou desrespeitar direitos, sendo assim, fazer com que uma Lei entre em vigor, só é possível através da humanidade ou desumanidade. Não se trata de um jogo de palavras, mas sim de demonstrar que é na sociedade que transformamos a própria sociedade, por meio de leis, decretos, mas, sobretudo, de atos e ações nas quais o outro, apresenta-se sempre como outro-eu. Para estudar as perspectivas da fraternidade na Nova Lei de Migrações brasileira, a Lei $n^{\circ} 13.445$, de 2017, faz-se necessário, primeiramente, apresentar o que é a fraternidade pelo viés da Metateoria do Direito Fraterno.

Diante disso, nesse primeiro capítulo, aborda-se o conceito e o desenvolvimento do Direito Fraterno por Eligio Resta. Ressalta-se que é importante observar qual é o significado da palavra fraternidade, que se origina do vocábulo latino frater, irmão. Na Grécia Antiga, a fraternidade estava vinculada ao âmbito da casa e da família -

9. RESTA (2004) p. 13. 
daoikia-, que eram as esferas da vida mais elementares e não possuíam a mesma importância que a participação na vida política da cidade ${ }^{10}$. Nesse momento histórico ainda não se vislumbra a fraternidade como um fator de mudança na sociedade, sendo a mesma, ainda, uma questão particular na vida das pessoas.

Essa compreensão sofre mudanças a partir da incorporação da palavra ao lema da Revolução Francesa -Liberté, Egalité, Fraternité-. A fraternidade passa a ter uma dimensão política, bem diferente daquela dimensão religiosa que possuía anteriormente. Contudo, somente sua participação no lema não foi suficiente para trazer ao conhecimento de todos a importância da fraternidade na sociedade. Isso aconteceu porque a Revolução Francesa sofreu influência da Independência Americana, em 1776 , caracterizando-se por possuir um forte traço individualista em seus ideais ${ }^{11}$. A liberdade e a igualdade conseguiram ajustar-se a essas ideias, no entanto, a fraternidade não, dado o fato de que a mesma requer um compartilhamento, o reconhecimento do outro.

Sendo assim, ela acaba por não receber a merecida atenção e este fato não se trata de um simples esquecimento, mas sim, de uma grande dificuldade de implementação do princípio básico de que todos são iguais, enquanto pertencentes à mesma humanidade, e que as diferenças existentes devem enriquecer, aproximar e não distanciar. Somente para exemplificar esse esquecimento, Baggio ${ }^{12}$ observa que, atualmente, o conceito de fraternidade não faz parte da estrutura de nenhuma disciplina que trate de política, como: direito, ciências sociais, história, filosofia. No entanto, são facilmente encontrados em dicionários e estudos dessas mesmas matérias os termos liberdade e igualdade que, juntamente com a fraternidade, formavam a tríade do lema da Revolução Francesa.

Esses acontecimentos justificam a afirmação de $\operatorname{Resta}^{13}$ de que a fraternidade era considerada a parente pobre, a prima do interior, já que permaneceu escondida durante a Revolução Francesa frente aos temas considerados mais urgentes na época, como a liberdade e a igualdade, deixando um vazio no lema da revolução. Além de ter

10. SAVAGNONE (2009) p. 449.

11. NICKNICH (2012) p. 172.

12. BAGGIO (2013) p. 35, tradução nossa. "This question is neither useless nor rethorical if we take into consideration that the concept of fraternity does not belong to any consolidated teaching of diverse disciplines dealing with politics such as the social and human sciences, economics, history, philosophy, and law. [...] Instead, we find the concepts of 'liberty' and 'equality' which, together with fraternity, composse the known 'triptych' (liberte, égalité, fraternité) of the French Revolution of 1789."

13. RESTA (2004) p. 9. 
perdido seu espaço, este não foi ocupado por outro princípio ${ }^{14}$ a fraternidade deveria ser o ponto de ligação entre a liberdade e a igualdade e, deixando o seu lugar vago, acabou por não desempenhar esse papel. Assim, a necessidade de retorno da fraternidade, anacronicamente, na atualidade, diz respeito à efetivação dos direitos que a liberdade e a igualdade, sozinhas, não conseguiram, pois produziram mais exclusões do que inclusões.

Para Resta, ${ }^{15} \mathrm{o}$ anacronismo tem o significado de contratempo. O contratempo é algo que não segue o tempo correto da história, ou seja, interrompe a linearidade dos acontecimentos. Nesse sentido, a fraternidade possui um sentido anacrônico, uma vez que ela retorna de uma época em que era esquecida, para a sociedade complexa, na qual não significa mais as divisões entre nações, mas justamente o seu contrário, a vida em conjunto. O retorno da fraternidade no direito encaminha a sociedade para a compreensão de que o direito é vida e, sendo assim, é muito mais do que lei escrita, é fruto de decisão. Dessa forma, "A fraternidade, então, não é outra coisa em relação à lei, nem assume a aparência de outro direito, mas talvez seja seu coração secreto, quanto mais central, mais problemas são as dimensões planetárias."16

Observa-se, então, que a fraternidade é permeada por paradoxos e ambiguidades, seus diversos significados e sentidos atravessam os séculos através da história da humanidade. A partir desses paradoxos e da reconstrução da ideia de fraternidade, Resta passa a estruturar sua teoria do Direito Fraterno, na década de 1980. Seu trabalho, Il diritto fraterno, acerca desse esquecimento e do retorno da fraternidade é publicado na década de 1990. Como visto acima, a volta da fraternidade mostra-se necessária, na atualidade, diante das exclusões que a liberdade e a igualdade, como princípios da Revolução Francesa, não conseguiram evitar.

Nesse sentido, "O Direito Fraterno trata de um tema cercado pelo anacronismo, por quanto a fraternidade, um dos pressupostos da Revolução Francesa, ressurge hoje em face da necessidade de se falar nela e de torná-la concreta." ${ }^{17}$ A Metateoria do Direito Fraterno, como Resta chamou seu estudo, seria a teoria das teorias, ou seja, uma teoria que analisa outras teorias. Nas palavras de Arnaud: ${ }^{18}$

14. VIAL y WÜNSCH (2013) pp. 4538-4539.

15. RESTA (2004) pp. 11-12.

16. RESTA (2005) p. vi, tradução nossa. "La fraternità allora non é altra cosa rispetto al diritto, né assume le vesti di un altro diritto, ma ne è forse il cuore segreto, tanto più centrale quanto più soluzione dei problemi appare legata a dimensioni planetarie".

17. STURZA y BRANDT (2006) p. 126.

18. ARNAUD (2000) p. 493. 
1. A metateoria é um tipo de atividade que pesquisa (a pesquisa metateórica), os resultados dessa atividade (a 'metateoria') 2. Pesquisa que tem por objetivo específico as teorias científicas (elas próprias consideradas também sob o ponto de vista da atividade e do seu produto) e que tem, como resultado, a produção de uma 'teoria das teorias científicas' (distinção feita em relação a interpretação jurídica -Tarello- entre metateoria como atividade e metateoria como produto).

Ao elaborar a ideia do Direito Fraterno, Resta faz uma análise transdisciplinar da sociedade. Tratar da transdisciplinaridade significa que os operadores do direito necessitam, constantemente, transgredir e integrar-se com outras áreas do conhecimento, com outras áreas da vida. Conforme Eligio Resta, o direito é o direito vivido, observações já estudas com profundidade por E. Erlich.

O direito tradicionalmente formado já não dá respostas adequadas para novos desafios que envolvem o ser no e para o mundo. O pertencer à sociedade não é, somente, estar fisicamente nela, dentro dos limites das nações, como era entendida a cidadania nos Estados-nações, mas sim incluir, integrar as pessoas e efetivar seus direitos humanos, independente de identidades.

Por conta dessa análise transdisciplinar, ao longo da Metateoria do Direito Fraterno, Eligio Resta apresenta diversas temáticas que são interligadas. Primeiramente, importante verificar que, por meio do Direito Fraterno, abre-se o sentido da fraternidade para algo maior que as fronteiras dos Estados-nação que, embora permeados pela igualdade e pela liberdade, tantas exclusões realizaram. Resta relata que muitas desilusões e decepções apareceram ao longo de sua obra, mas servem para confirmar a diferença da fraternidade nas leis e na prática dentro dos limites dos Estados, na qual ela não se abria a uma civitas maxima ${ }^{19}$.

$\operatorname{Resta}^{20}$ destaca que a fraternidade surge como um princípio do direito internacional ainda nascente, fundada na ideia de Estados Nacionais. Ao mesmo tempo em que se abria para nações e povos além de suas fronteiras, também se fechava, incluía, excluindo. A fraternidade "abria, portanto, o cenário do cosmopolitismo, mas o fechava imediatamente dentro do recinto das pertenças a famílias nacionais," ${ }^{21}$ ou seja, ao mesmo tempo em que aproximava os indivíduos, evidenciava a diferenciação dos

19. RESTA (2005) p. vi, tradução nossa. "Alcune possibili delusioni sono già anticipate e attraversano il libro, ma non fanno che confermale lo scarto tra la fraternità richiamata dalle leggi e la pratica dei comportamenti quotidiani dentro i confini angusti degli stati e in quello spazio planetario liscio, aperto più alla competizione hobbesiana che non alla forma della civitas máxima".

20. RESTA (2004) pp. 9-10.

21. RESTA (2004) p. 10. 
mesmos, conforme suas origens e dividia o mundo em nações isoladas umas das outras, nas quais os direitos de todos, embora humanos, têm diferenciações dentro de cada território.

Quando a fraternidade retorna, anacronicamente, ela apresenta uma nova dimensão de pertencimento de todos, de elo entre todos, de consciência de distanciarse da lógica da inimizade, compartilhando espaços comuns. ${ }^{22}$ Resta $^{23}$ observa que, se o retorno anacrônico da fraternidade representa seu novo sentido na sociedade, faz-se necessário transformá-la em código, em regra, mesmo com os paradoxos que representa um código fraterno. Ainda, partindo dessa visão de mundo dividido em Estados-nações, é que Resta desenvolve o estudo da amizade, pois os limites geográficos criados pela política internacional representam os limites do reconhecimento de quem é amigo e de quem é inimigo. "O paradoxo da amizade está todo ali, na geografia, no tempo do próximo, na fronteira entre a vida pública e a vida privada por um lado, e a vida comum por outro, no difícil divisor de águas entre a comunidade dos amigos e a comunidade." ${ }^{24}$

O código fraterno das comunidades políticas tinha o papel de aproximar as pessoas que conviviam dentro dos limites de determinada nação. Contudo, ele cobrava, em contrapartida, a vinculação à cidadania do local, assim, em caso de transgressão, o indivíduo, dentro desses limites, é criminoso, opositor político ou minoria, mas não chega a ser um "inimigo", pois a amizade política está no interior e a inimizade no exterior. ${ }^{25}$ Esse código fraterno parte do princípio de que "[...] somos amigos porque existem inimigos, somos amigos porque não somos estranhos, somos amigos porque nos escolhemos para nos contrapormos a outras formas de relações impostas ou involuntárias.” 26

Diante disso, Resta ${ }^{27}$ observa no Direito Fraterno o retorno da fraternidade em uma sociedade complexa. Ele mostra que a humanidade é como a ecologia, isto é, não possui somente ar despoluído e rio límpido, também apresenta ambiguidades/ paradoxos, como a ideia de que a humanidade ameaça a si mesma, mas, ao mesmo tempo, tutela seus próprios direitos.

22. RESTA (2005) p. vii, tradução nossa."La fraternità è soltanto consapevolezza di dover prendere distanza dalle logiche dellinimicizia e condividere spazi comuni a ogni altro individuo, con la sua vita, storia, dignità."

23. RESTA (2004) p. 11.

24. Op. cit., p. 37.

25. Op. cit., pp. 34-35.

26. Op. cit., p. 25.

27. Op. cit., p. 52. 
O direito fraterno coloca, pois, em evidência, toda a determinação histórica do direito fechado na angústia dos confins estatais e coincide com o espaço de reflexão ligado ao tema dos Direitos Humanos, com uma consciência a mais: a de que a humanidade é simplesmente o lugar "comum", somente em cujo interior pode-se pensar o reconhecimento e a tutela. Em outras palavras: os Direitos Humanos são aqueles direitos que somente podem ser ameaçados pela própria humanidade, mas que não podem encontrar vigor, também aqui, senão graças à própria humanidade ${ }^{28}$.

Resta $^{29}$ concebe o Direito Fraterno como uma forma de criação de auto-responsabilização na seara dos direitos humanos, libertando a sociedade da rivalidade dos “irmãos-inimigos". Ao retornar na sociedade complexa, a fraternidade, como código fraterno, procura direcionar o direito à civitas maximas e não às pequenas pátrias, mesmo que ainda haja a paradoxal situação de inclusão e exclusão. O Direito Fraterno é um modelo que abandona os confins fechados da cidadania e projeta para uma nova forma de cosmopolitismo, para uma nova forma de codivisão, de compartilhamento, de enxergar o outro como o outro-eu.

Assim como a fraternidade passou a ser reconhecida como o elo que faltou entre a liberdade e a igualdade para que essas duas efetivassem os direitos humanos na sociedade, o Direito Fraterno é a aposta no rompimento entre humanidade, cidadania e nacionalidade, apresentando a ideia de uma civitas maxima na qual todos terão assegurados os seus direitos humanos, independentemente do território do nascimento. Embora a atual organização internacional ainda seja formada por Estados soberanos que delimitam suas fronteiras e dão permissão para entrada em seu território, algumas mudanças já foram realizadas para que todo ser humano seja visto como indivíduo pertencente a uma mesma humanidade.

\section{Fraternidade e fluxos migratórios: o direito de migrar e a presença do outro como o "OUTRO-EU"}

"Valha para todos o exemplo das legislações em relação aos problemas imigratórios, nos quais pavorosamente a inimizade mostra novamente sua cara: é verdade que infelizmente isso acontece e que prevalece o miope egoísmo de quem pensa em termos de pequenas e estéreis devoções, mas poderia ser diferente, e nem sempre essas outras possibilidades são adequadamente cultivadas." ${ }^{\circ}$

28. RESTA (2004) p. 13.

29. Op. cit., pp. 12-14.

30. RESTA (2004) p. 15. 
A Metateoria do Direito Fraterno apregoa uma nova forma de olhar a realidade, propõe ver nos limites, também as possibilidades. A realidade a ser observada pode ser a dos fluxos migratórios, pois ao mesmo tempo em que unem pessoas -ao juntar diversas nacionalidades em um local-, também as afastam diante de atitudes xenófobas, muitas vezes realizadas por uma população desinformada e mídias que manipulam a realidade. Esse paradoxo de acolhimento e expulsão, presentes na atualidade diante dos fluxos migratórios intensos e constantes, retrata bem a ambivalência das inclusões e exclusões, já mencionadas anteriormente, e que são evidentes nas políticas migratórias. Neste tópico, será estudado o direito de migrar e os paradoxos ainda presentes na sociedade cosmopolita.

Para isso, primeiramente, deve-se entender que as migrações sempre estiveram presentes na história da humanidade. As comunidades tomaram forma com o deslocamento de pessoas pela Terra. O ato de migrar, então, é o processo de atravessar fronteiras: "É um movimento populacional que compreende qualquer deslocação de pessoas, independentemente da extensão, da composição ou das causas; inclui a migração de refugiados, pessoas deslocadas, pessoas desenraizadas e migrantes econômicos." ${ }^{31}$ Contudo, Köcke faz um alerta para o fato de que, atualmente, não é simples a distinção entre a migração espontânea (relacionada com os migrantes econômicos) e a migração forçada (relacionada com situações de refúgio).

(...) não é apenas a perseguição e a violência física que levam as pessoas a deixarem seus lares. O termo "migração espontânea" esconde a gama de fatores que influenciam e determinam o fenômeno migratório, que certamente transcende a mera manifestação da vontade singularizada do migrante, maculando a crença da espontaneidade do fenômeno. Nas migrações econômicas, a violência simbólica operada pela desigualdade racial corrompe a voluntariedade da decisão de migrar, que jamais poderia ser entendida como espontânea ${ }^{32}$.

Isso ocorre pelo fato de que novas violações de direitos humanos têm ameaçado as pessoas e as obrigado a migrar, sem, contudo, que haja uma atualização legislativa para o reconhecimento de determinado status, como é o caso do refúgio. Ainda, por englobar todas as situações relatadas acima, é comum haver a confusão de nomenclatura nas migrações no momento de caracterizar determinada pessoa ou determinado grupo que está em fluxo, contudo, deve atentar-se a cada particularidade para que as respostas de auxílio possam ser adequadas.

31. OIM (2009) p. 40.

32. KÖCKE (2015) p. 29. 
Até o término da Segunda Guerra Mundial, migrar não era visto como um direito humano. Foi diante das barbáries cometidas pelo regime nazista que as nações passaram a se preocupar com a criação de mecanismos para a garantia de proteção dos seres humanos em âmbito internacional pois, antes desse acontecimento, o indivíduo era relegado a um plano inferior ${ }^{33}$. Surge, então, a compreensão de que o ser humano não é objeto de direito internacional público, mas é sujeito, podendo reivindicar seus direitos na esfera internacional de proteção dos direitos humanos ${ }^{34}$.

A alteração causada pela internacionalização dos direitos humanos afeta a soberania estatal, uma vez que os direitos saem do domínio reservado do Estado, migrando para uma posição supranacional ${ }^{35}$. "[...] essa nova concepção afasta de vez o velho conceito de soberania estatal absoluta, que considerava, na acepção tradicional, os Estados os únicos sujeitos do direito internacional público." ${ }^{36}$ Nesse mesmo sentido, tem-se a visão do Direito Fraterno:

O direito fraterno coloca, pois, em evidência, toda a determinação histórica do direito fechado na angústia dos confins estatais e coincide com o espaço de reflexão ligado ao tema dos Direitos Humanos, com uma consciência a mais: a de que a humanidade é simplesmente o lugar "comum", somente em cujo interior pode-se pensar o reconhecimento e a tutela. Em outras palavras: os Direitos Humanos são aqueles direitos que somente podem ser ameaçados pela própria humanidade, mas que não podem encontrar vigor, também aqui, senão graças à própria humanidade ${ }^{37}$.

Contudo, o ciclo desse reconhecimento não está completo, pois, paradoxalmente, ao mesmo tempo em que é crescente o reconhecimento do indivíduo como detentor de direitos, independentemente de sua nacionalidade, há, ainda, a implementação desses direitos pelos Estados ${ }^{38}$. Atualmente, não há nação que negue uma carta de direitos, o que não significa uma garantia de justiça concreta, já que cada direito varia conforme o pensamento político e filosófico do Estado a que está submetido ${ }^{39}$. No caso específico das migrações, o Estado continua a possuir o monopólio da legitimidade da mobilidade, como um fundamento de sua soberania ${ }^{40}$. Observa-se que, na es-

33. GUERRA (2017) pp.105-107.

34. MAZZUOLI (2014) p. 53.

35. GUERRA (2017) p. 123.

36. MAZZUOLI (2014) p. 52.

37. RESTA (2004) p. 13.

38. REIS (2004) p. 154.

39. GUERRA (2015) p. 40.

40. REIS (2004) p. 150. 
fera internacional, as nações concordam com a proteção de direitos humanos a todos, entretanto, quando esse "todos" escolhe ultrapassar suas barreiras, volta-se à ideia do código fraterno pós-westfália, trazendo à tona a ideia da formação dos cristais, em que há atração, mas também coesão ${ }^{41}$.

Embora o direito de migrar seja um direito humano reconhecido no sistema global -artigo 13 da Declaração Universal dos Direitos Humanos e artigo 12 do Protocolo Internacional sobre Direitos Civis e Políticos- e nos sistemas regionais de proteção dos direitos humanos, o que se verifica, atualmente, é o crescimento de políticas restritivas quanto à migração, gerando a construção de muros entre as nações ao invés de pontes, que poderiam servir de auxílio aos migrantes. Todas essas variáveis e contradições, na visão de Bauman ${ }^{42}$, são as causadoras da desumanização dos migrantes, pessoas desprovidas de significação. A desumanização vira exclusão, ocasionando consequências nefastas para os indivíduos, que saem da esfera ética e passam à da insegurança e criminalidade.

Resta $^{43}$ relata a diferenciação realizada na comunidade política em relação ao interno e o externo. Ao inimigo interno era dado o nome de criminoso ou minoria. "É exatamente aquela definida por uma lei da amizade que encontra nos processos de codificação moderna a fórmula do imperativo da fraternidade diante de um jogo político, construído em cima da contraposição, conhecida, do amigo-inimigo." ${ }^{44} \mathrm{Em}$ virtude disso, compara a humanidade à ecologia, ao dizer que estas são formadas por situações diversas do rio límpido e do ar despoluído, apresentando o paradoxo de que somente a humanidade pode ameaçar a própria humanidade ${ }^{45}$.

Assim, a função da fronteira, além de ser de inclusão/exclusão das porções territoriais, também é de inclusão/exclusão de pessoas, já que fora dos limites do Estado está o outro, o alienígena, aquele que não pertence à vida pública por ser diferente ${ }^{46}$. Essa visão traz consequências negativas para os direitos humanos e para os fluxos migratórios, pois a vida do migrante fica condicionada à identificação com algum Estado, não sendo uma vida simplesmente por ser humano. As perdas que envolvem a vida do refugiado são tantas, que ele acaba por perder sua própria condição de ser humano.

Para Ventura ${ }^{47}$, as políticas migratórias restritivas são mais presentes em países desenvolvidos, já nos países em desenvolvimento, de modo geral, não há tamanha

41. RESTA (2004) p. 29.

42. BAUMAN (2017) p. 84.

43. RESTA (2004) p. 34.

44. Op. cit., pp. 19-20.

45. Op. cit., p. 52.

46. LISOWSKI (2012) p. 117.

47. VENTURA (2015) p. 58. 
restrição. No entanto, a ausência de políticas migratórias efetivas produz efeitos equivalentes aos das políticas restritivas. Ao cruzar fronteiras porosas, encontra-se dificuldade com a regularização migratória, criando-se uma situação migratória irregular, que torna a pessoa mais suscetível a precarizações (trabalho saúde, inclusão social e econômica). Isso ocorre, por exemplo, nos Brics (Brasil, Rússia, Índia, China e África do Sul), e o número de pessoas deslocadas só aumenta.

Segundo dados do ACNUR ${ }^{48}$, ao final de 2017, havia 68,5 milhões de pessoas deslocadas forçadamente no mundo, por causa de guerras, conflitos e violência generalizada. Desse número, 25,4 milhões eram refugiados, 40 milhões eram deslocados internos e 3,1 milhões eram solicitantes de asilo ${ }^{49}$. Esse número representa 16,2 milhões de novos deslocados, 44.400 a cada dia. As regiões em desenvolvimento acolhem 85\% dos refugiados do mundo, o Líbano é o país que mais acolhe refugiados em relação à sua população, 1 em cada 6 pessoas é refugiada no Líbano. A Turquia, por sua vez, é o país que mais acolhe refugiados no geral.

Com a criação das Nações Unidas as diversas nações signatárias afirmaram sua preocupação com os direitos humanos. Especificamente quanto à temática dos fluxos migratórios, as Nações Unidas já ratificaram Convenções e Protocolos, porém, alguns continuam com pouca adesão, conforme observa Ventura ${ }^{50}$ em relação à Convenção das Nações Unidas sobre a Proteção dos Direitos dos Trabalhadores Migrantes e de suas Famílias, adotada em 1990 e que, até hoje, recebeu a aceitação de 48 Estados apenas. O grande desafio relacionado ao estudo dos fluxos migratórios diz respeito à compreensão, por parte das nações, de que esses são comuns na história da humanidade e que precisam de políticas a longo prazo, para que os direitos humanos dos migrantes não sejam ameaçados e violados.

Estar na humanidade é ser humano, ${ }^{51}$ mas o que a Metateoria do Direito Fraterno apresenta é que esta relação não significa ter humanidade no sentido de enxergar o outro como o "outro-eu". Pode-se exemplificar esta condição com a situação dos

\section{ACNUR (2018) pp. 2-3.}

49. Para o relatório do Acnur, o solicitante de asilo é entendido como a pessoa que busca proteção internacional, mas a solicitação de refúgio está pendente de análise. ACNUR (2018) p. 61, tradução nossa. "[...] son las personas que han solicitado protección internacional y cuya solicitud de la condición de refugiado está pendiente de resolución. A efectos de este informe, se ha tenido en cuenta a los solicitantes cuya petición de asilo individual estaba pendiente de resolución al final de 2017, sin tener en cuenta cuándo fue presentada."

50. VENTURA (2015) p.58.

51. Para Bouchet-SAULNIER (1998) pp. 207-213, os direitos do homem abrangem “(...) os direitos de que qualquer pessoa goza. São o reconhecimento jurídico da dignidade humana e da igualdade entre os homens. Esses direitos são indispensáveis no desenvolvimento da pessoa." 
fluxos migratórios aqui estudados, pois, embora estes sejam constantes e intensos, muito diferentes das migrações dos séculos XVIII e XIX, que possuíam um viés muito mais econômico e colonial, o que se observa, agora, é o fechamento das fronteiras nacionais, impedindo a entrada das pessoas:

Os problemas gerados pela "crise migratória" atual e exacerbados pelo pânico que o tema provoca pertencem à categoria dos mais complexos e controversos: neles, o imperativo categórico da moral entra em confronto direto com o medo do "grande desconhecido" simbolizado pelas massas de estranhos à nossa porta ${ }^{52}$.

A fraternidade retornou, anacronicamente, para desvelar paradoxos, pois o que se verifica na atualidade é uma total descrença em construir pontes ao invés de muros, diante do grande fluxo migratório existente e do medo em relação ao quem vem de fora. Os paradoxos apresentam os limites e as possibilidades que são visíveis, diariamente, na sociedade formada por migrantes e nacionais. Possiblidades de nova vida, de novos postos de trabalho, possibilidades de recomeço, mas também limites econômicos do país de destino, limites no idioma e na cultura. No caso brasileiro, a publicação de uma Nova Lei de Migrações apresenta a mudança de uma visão do migrante voltada para a segurança nacional, para uma visão dos direitos humanos, apresentando, assim, ideias que vão ao encontro do Direito Fraterno.

\section{Migração no Brasil: do estatuto do estrangeiro à nova Lei de Migrações (Lei No 13.445 DE 2017)}

"[...] somos amigos porque existem inimigos, somos amigos porque não somos estranhos, somos amigos porque nos escolhemos para nos contrapormos a outras formas de relações impostas ou involuntárias." ${ }^{33}$

Em 24 de maio de 2017, o Brasil publica sua Nova Lei de Migrações -a Lei No 13.445-, que entra em vigor em 180 dias, em novembro de 2017. Em quase um ano de aplicação, a Nova Lei substituiu o já defasado Estatuto do Estrangeiro, da Ditadura Militar, Estatuto este que possuía uma visão limitada da migração em que o migrante era o estrangeiro que necessitava ser contido pelo Estado, com uma visão de segurança nacional. A Nova Lei apresentou muitas novidades positivas ao reconhecer direitos aos migrantes e, algumas questões negativas, como a publicação do Decreto No 9.199, de 20 e novembro de 2017 que, na contramão da Nova Lei, retira direitos. Para compreender como se chegou até essa legislação atualmente em vigor e analisá-la por um viés do Direito Fraterno, é importante fazer um breve estudo acerca do reconhecimento dos migrantes no Brasil.

52. BAUMAN (2017) p. 104.

53. RESTA (2004) p. 25. 
Conforme já apresentado, estava em vigor, no Brasil, a Lei № 6.815 de 1980, conhecida como Estatuto do Estrangeiro. Morais e Barros ${ }^{54}$ reconhecem que o Brasil e a maior parte dos países da América Latina, nessa década, tiveram a legislação migratória e de segurança nacional contagiadas pela ideia de inimizade, impedindo o reconhecimento do outro como sujeito de direitos fundamentais. "A questão por trás de tais instrumentos legislativos foi justamente transverter a inimizade entre Estados em uma inimizade entre pessoas, cidadãos, de modo a desconhecer os seus direitos fundamentais." ${ }^{55}$ A existência dessas práticas legislativas de criação de inimizades leva Resta a questionar sobre o que são os crimes contra a humanidade. Se a humanidade é o lugar onde as pessoas se conhecem, ou seja, são todos humanos, ecologicamente, quase uma dimensão orgânica da política, quem, então, realiza o crime contra a humanidade? Não é essa mesma humanidade a quem se deveria proteger?56

No Brasil, ao escolher criar pontes, o fundamento maior da proteção dos migrantes é a Constituição Federal de 1988. A Constituição, também, apresenta a fraternidade como um valor maior do Estado. Machado menciona que o legislador brasileiro contemplou a moldura jurídico-constitucional preocupado com a construção de um Estado Fraternal. ${ }^{57}$ Por meio do preâmbulo, ${ }^{58}$ indicou valores supremos de uma sociedade fraterna a ser alcançada. Diante desse compromisso, todos, Estados, governo, povo e sociedade civil passaram a ser responsáveis não somente pela construção de uma sociedade voltada aos nacionais, cidadãos, mas a uma sociedade de irmãos.

54. MORAIS y BARROS (2015) p. 149.

55. Op. cit., p. 156.

56. RESTA (2015) p.18, tradução nossa. "[...] cosa sono i crimini contro natura? E soprattutto i crimini contro natura sono i crimini contro l'umanità? Se l'umanità è il luogo in cui ci riconosciamo tutti uomini e quindi, ecologicamente, ci rappresentiamo tutti, quase uma dimensione organicística della politica stessa, chi compie i crimini contro l'umanità? Non è la stessa umanità che si vuole proteggere? A meno che non pensiamo di riferirci a dei marziani (anche se la legge, a volte, fa sospettare che sai così!)."

57. MACHADO (2015) p. 11.

58. "Nós, representantes do povo brasileiro, reunidos em Assembléia Nacional Constituinte para instituir um Estado Democrático, destinado a assegurar o exercício dos direitos sociais e individuais, a liberdade, a segurança, o bem-estar, o desenvolvimento, a igualdade e a justiça como valores supremos de uma sociedade fraterna, pluralista e sem preconceitos, fundada na harmonia social e comprometida, na ordem interna e internacional, com a solução pacífica das controvérsias, promulgamos, sob a proteção de Deus, a seguinte CONSTITUIÇÃO DA REPÚBLICA FEDERATIVA DO BRASIL." BRASIL (1988). 
Unindo a ideia de fraternidade e migração, alguns dispositivos constitucionais auxiliam no fundamento da proteção desses migrantes. No artigo $1^{\circ}$, inciso III, observase que: "A República Federativa do Brasil, formada pela união indissolúvel dos Estados e Municípios e do Distrito Federal, constitui-se em Estado Democrático de Direito e tem como fundamentos: [...] III - a dignidade da pessoa humana; [...]".59 Assim, "Por ser condição humana interior, a dignidade exterioriza-se através da fraternidade, no processo de reconhecimento da dignidade do outro." ${ }^{60} \mathrm{O}$ reconhecimento da dignidade do outro somente é possível por meio da cooperação, do compartilhamento de responsabilidades e da integração com respeito às diferenças.

$\mathrm{Na}$ ordem internacional, tais práticas são muito importantes para que as nações possam obter auxílio mútuo nas questões migratórias e, por isso, foram elencadas por meio dos princípios do artigo $4^{\circ}$, merecendo atenção o inciso II, prevalência dos direitos humanos; o inciso IX, cooperação entre os povos e o inciso $x$, concessão de asilo político. ${ }^{61}$ Jubilut entende que:

Com base nesses princípios, pode-se afirmar que os alicerces da concessão do refúgio, vertente dos direitos humanos e espécie do direito de asilo, são expressamente assegurados pela Constituição Federal de 1988, sendo ainda elevados à categoria de princípios de nossa ordem jurídica. Sendo assim, a Constituição Federal de 1988 estabelece, ainda que indiretamente, os fundamentos legais para a aplicação do instituto do refúgio pelo ordenamento jurídico brasileiro ${ }^{62}$.

$\mathrm{O}$ artigo $5^{\circ}$ expõe que "Todos são iguais perante a lei, sem distinção de qualquer natureza, garantindo-se aos brasileiros e aos estrangeiros residentes no País a inviolabilidade do direito à vida, à liberdade, à igualdade, à segurança e à propriedade, [...]".63 Por fim, o artigo 22 da Constituição Federal de 1988, em seu inciso XV, apresenta que

59. BRASIL (1988).

60. RESTA et al. (2017) p. 99.

61. BRASIL (1988).

62. JUBILUT (2007) p. 181.

63. BRASIL (1988). Quanto ao reconhecimento da ordem internacional, o artigo $5^{\circ}$ apresenta em seus parágrafos o seguinte: “[...]\$ $2^{\circ}$ Os direitos e garantias expressos nesta Constituição não excluem outros decorrentes do regime e dos princípios por ela adotados, ou dos tratados internacionais em que a República Federativa do Brasil seja parte. $\$ 3^{\circ}$ Os tratados e convenções internacionais sobre direitos humanos que forem aprovados, em cada Casa do Congresso Nacional, em dois turnos, por três quintos dos votos dos respectivos membros, serão equivalentes às emendas constitucionais. $\$ 4^{\circ} \mathrm{O}$ Brasil se submete à jurisdição de Tribunal Penal Internacional a cuja criação tenha manifestado adesão. [...]". 
compete privativamente à União legislar sobre emigração e imigração, entrada, extradição e expulsão de estrangeiros. Nenhuma dessas ações seria possível se, a partir da Constituição Federal de 1988, o Brasil não tivesse direcionado sua política por uma via de respeito aos direitos humanos, tolerância e convivência com o outro e de compartilhamento de responsabilidades, já que todos pertencem à mesma humanidade.

Atualmente, com a Nova Lei de Migrações continua a preocupação com os direitos humanos. Para Guerra, ${ }^{64}$ a Nova Lei traz como principais mudanças: a desburocratização do processo de regularização migratória, a institucionalização da política de vistos humanitários e a não criminalização por razões migratórias. A Nova Lei de Migrações foi toda elaborada com a plena participação das entidades da sociedade civil que atuam na causa dos fluxos migratórios, objetivando apresentar um rol de direitos, mas também deveres dos migrantes que chegam ao Brasil. Ocorre que, para sua implementação, foi publicado o Decreto $n^{\circ}$ 9.199, sem qualquer participação da sociedade civil e o teor apresenta um retrocesso em relação ao já exposto na Nova Lei.

Segundo especialistas que formaram a Comissão constituída pelo Ministério da Justiça para elaborar o Anteprojeto de Lei de Migrações e Promoção dos Direitos dos Migrantes no Brasil (2013-2014), a regulamentação da Nova Lei foi submetida a uma brevíssima consulta pública, razão pela qual apresenta disposições que desvirtuam o espírito da Nova Lei. O Decreto nº 9.199 representa uma afronta às conquistas históricas dos direitos dos migrantes e à capacidade do Estado brasileiro de formular políticas adequadas em relação a este ${ }^{65}$.

Diante do exposto, observa-se que o Brasil evoluiu muito em relação à política e legislação migratória. A Nova Lei de Migrações foi criada com um olhar voltado para os direitos humanos, ao compartilhamento e reconhecimento do outro como o outro-eu, no sentido de acolhimento, mas também de empoderamento desses migrantes que chegam ao solo brasileiro. Embora o Decreto $\mathrm{n}^{\circ} 9.199$ apresente ideias destoantes aos princípios dispostos pela Nova Lei, cabe às entidades da sociedade civil, bem como aos organismos governamentais que atuam com a causa migratória, fiscalizar e cobrar a aplicação adequada da nova legislação.

Ao analisar o texto da Nova Lei, que possui 125 artigos, divididos em 10 capítulos, pode-se localizar muitas ideias e características que vão ao encontro dos conceitos elencados na Metateoria do Direito Fraterno, de Eligio Resta. Assim, para que seja feita essa aproximação entre o Direito Fraterno e a Nova Lei de Migrações, no próximo tópico serão analisados os pressupostos do Direito Fraterno em conjunto com as disposições da Lei de Migrações brasileira.

64. GUERRA (2017) p. 472.

65. RAMOS et al. (2017). 


\section{Perspectivas da fraternidade na nova lei de migrações}

"O Direito Fraterno, então, vive sem fundamento, torna-se animada com fraquezas; olha-se bem afirmando que 'deve' ser, e que há uma verdade que o move. Pelo contrário, arrisca uma aposta, assim como na aposta de Pascal na existência do bem comum: se existisse, o benefício teria sido enormemente maior do que o custo usado com sua própria contribuição pessoal."66

Como visto no tópico anterior, o Brasil passou por muitas mudanças em sua legislação migratória. No início, por conta de uma Ditadura Militar, criou-se o Estatuto do Estrangeiro. Na sequência, com a redemocratização em 1988, os ares começam a mudar e as primeiras ideias de efetivação de direitos humanos iguais a brasileiros e migrantes aparecem. A fraternidade já está presente na Constituição Federal de 1988 e, por essa escolha de compartilhamento, de pertencimento e de acolhida ao outro é que o Direito Fraterno se manifesta. Agora, com a Nova Lei de Migrações em vigor, e apresentando, a cada dia, alternativas para que os migrantes que chegam ao território brasileiro tenham seus direitos humanos respeitados, é importante conectá-la à ideia do Direito Fraterno, por meio dos pressupostos apresentados por Eligio Resta.

No último capítulo de sua obra intitulado "Per um diritto fraterno", Resta expõe que: "O passo não é fácil, mas, desviando o olhar do código do amigo-inimigo e liberando-se daquela singular obsessão da política como ideia da neutralização da hostilidade, abrem-se outros horizontes." ${ }^{67}$ Assim, buscando essa abertura, ele resgata, ao final de seu estudo, as passagens fundamentais expostas no arcabouço do Direito Fraterno e apresenta-as na forma de oito pressupostos de sua Metateoria. A seguir, serão realizadas as intersecções entre esses pressupostos e a Nova Lei de Migrações.

66. RESTA (2005) p. 134, tradução nossa. "Il diritto fraterno, allora, vive d'infondatezze, si anima di debolezze; si guarda bene dall' affermare che 'deve' essere, e che c'è una verità che lo muove. Al contrario rischia una posta, esattamente come nella scommessa di Pascal sull'esistenza del bene comune: se fosse esistito, il beneficio sarebbe stato enormemente più grande del costo impiegato col proprio personale contributo."

67. RESTA (2005) p. 131, tradução nossa. "Il passo non è facile, ma, deviando lo sguardo dal códice dell'amico-nemico e liberandosi da quella singolare ossessione della politica come idea della neutralizzazione dell'ostilità, si aprono altri orizzonti." 
A Nova Lei dispõe sobre os direitos e os deveres dos migrantes, regula a entrada e estada no Brasil e estabelece princípios e diretrizes para as políticas públicas para o emigrante, conforme artigo $1^{\mathrm{o68}}$. Não se utiliza mais a palavra "estrangeiro", como no antigo Estatuto, pois não se busca um viés de segurança nacional, mas sim de integração e promoção dos direitos humanos. No artigo $2^{\circ}$, a Lei apresenta o conceito de cada tipo de migração, o que é de suma importância para que a adequada política pública seja aplicada em cada caso ${ }^{69}$.

$\$ 1$ o Para os fins desta Lei, considera-se:

I- (VETADO);

II- imigrante: pessoa nacional de outro país ou apátrida que trabalha ou reside e se estabelece temporária ou definitivamente no Brasil;

III- emigrante: brasileiro que se estabelece temporária ou definitivamente no exterior;

IV- residente fronteiriço: pessoa nacional de país limítrofe ou apátrida que conserva a sua residência habitual em município fronteiriço de país vizinho;

V- visitante: pessoa nacional de outro país ou apátrida que vem ao Brasil para estadas de curta duração, sem pretensão de se estabelecer temporária ou definitivamente no território nacional;

VI- apátrida: pessoa que não seja considerada como nacional por nenhum Estado, segundo a sua legislação, nos termos da Convenção sobre o Estatuto dos Apátridas, de 1954, promulgada pelo Decreto $\mathrm{N}^{\circ}$ 4.246, de 22 de maio de 2002, ou assim reconhecida pelo Estado brasileiro ${ }^{70}$.

Os artigos $3^{\circ}$ e $4^{\circ}$ estão contidos na seção II, que apresenta os Princípios e as Garantias. Segundo a Nova Lei, a política migratória brasileira deve ser regida por princípios que reconheçam direitos iguais a nacionais e a migrantes, por isso, elenca no inciso I, a universalidade, indivisibilidade e interdependência dos direitos humanos. $\mathrm{Na}$ sequência, apresenta princípios como os da não-discriminação (IV); não criminalização das migrações (III); combate à xenofobia (II); promoção de regularização

68. BRASIL (2017).

69. Após a publicação da Nova Lei de Migrações, Lei № 13.445 de 2017, os Ministérios de Estado e Justiça, Ministério Extraordinário da Segurança Pública, Ministério das Relações Exteriores e Ministério do Trabalho publicaram e continuam a publicar Portarias Interministeriais que regulamentam algumas formas de autorização de residência descritas na Nova Lei de Migrações. Até o fechamento deste artigo, 15 Portarias Interministeriais foram publicadas.

70. BRASIL (2017). 
migratória (V, VI); inclusão social do migrante $(\mathrm{X})$ com acesso a serviços de saúde, educação e assistência social (XI) e, também, a difusão de direitos e obrigações (XII)71. (BRASIL, 2017). A apresentação dos direitos e obrigações dos migrantes vão ao encontro do primeiro pressuposto da Metateoria do Direito Fraterno:

a) O Direito Fraterno é um direito jurado em conjunto por irmãos, homens e mulheres, com um pacto em que se "decide compartilhar" regras mínimas de convivência. Então, é convencional, com o olhar voltado ao futuro. O seu oposto é o "direito paterno", que é o direito imposto pelo pai senhor da guerra a quem se deve somente

71. Art. 3o A política migratória brasileira rege-se pelos seguintes princípios e diretrizes: I- universalidade, indivisibilidade e interdependência dos direitos humanos; II- repúdio e prevenção à xenofobia, ao racismo e a quaisquer formas de discriminação; III- não criminalização da migração; IV- não discriminação em razão dos critérios ou dos procedimentos pelos quais a pessoa foi admitida em território nacional; V- promoção de entrada regular e de regularização documental; VI- acolhida humanitária; VII- desenvolvimento econômico, turístico, social, cultural, esportivo, científico e tecnológico do Brasil; VIII- garantia do direito à reunião familiar; IX- igualdade de tratamento e de oportunidade ao migrante e a seus familiares; X- inclusão social, laboral e produtiva do migrante por meio de políticas públicas; XI- acesso igualitário e livre do migrante a serviços, programas e benefícios sociais, bens públicos, educação, assistência jurídica integral pública, trabalho, moradia, serviço bancário e seguridade social; XII- promoção e difusão de direitos, liberdades, garantias e obrigações do migrante; XIII- diálogo social na formulação, na execução e na avaliação de políticas migratórias e promoção da participação cidadã do migrante; XIV- fortalecimento da integração econômica, política, social e cultural dos povos da América Latina, mediante constituição de espaços de cidadania e de livre circulação de pessoas; XV- cooperação internacional com Estados de origem, de trânsito e de destino de movimentos migratórios, a fim de garantir efetiva proteção aos direitos humanos do migrante; XVI- integração e desenvolvimento das regiões de fronteira e articulação de políticas públicas regionais capazes de garantir efetividade aos direitos do residente fronteiriço; XVII- proteção integral e atenção ao superior interesse da criança e do adolescente migrante; XVIII - observância ao disposto em tratado; XIX - proteção ao brasileiro no exterior; XX- migração e desenvolvimento humano no local de origem, como direitos inalienáveis de todas as pessoas; XXI- promoção do reconhecimento acadêmico e do exercício profissional no Brasil, nos termos da lei; e XXII- repúdio à práticas de expulsão ou de deportação coletivas. (BRASIL, 2017). 
jurar (ius iurandum). A coniuratio dos irmãos não é contra o pai, ou um soberano, um tirano, um inimigo, mas é para uma convivência compartilhada, livre da soberania e da inimizade. Esse é jurado em conjunto, mas não é produto de uma trama ${ }^{72}$.

A ideia do Direito Fraterno é a convivência compartilhada, já que se está em uma relação fraterna, de igual para igual. Nacionais e migrantes pertencem à mesma humanidade, com direitos e deveres que devem ser respeitados. A concretização dos princípios elencados no artigo $3^{\circ}$ da Nova Lei somente ocorrerá com a divisão de responsabilidades entre governos, sociedade e migrantes. Auxiliando nessas práticas, a Lei de Migrações, ao retirar a palavra "estrangeiro" e todo o seu estigma negativo, dá o primeiro passo para que essa igualdade esteja cada vez mais presente nas políticas públicas brasileiras. Essa ideia vai, também, ao encontro do segundo pressuposto elencado por Eligio Resta, em que se apresenta o Direito Fraterno livre da obsessão da identidade:

b) Por isso é livre da obsessão da identidade que deve legitimá-lo. É distante de um ethnos que o justifica, mas pronto a constituir um demos graças a um pacto. A sua "raiz errante" encontra o seu terreno em um espaço político aberto, privado daquele território que, mais ou menos artificialmente, justifica o domínio. Não pede outra justificação que a com-munitas, exatamente a tarefa compartilhada ${ }^{73}$.

72. RESTA (2005) p. 132, tradução nossa."a) il diritto fraterno è un diritto giurato insieme da fratelli, uomini e donne, com um patto in cui si 'decide di condividere' regole minime di convivenza. Dunque è convenzionale, con lo sguardo rivolto al futuro. Il suo oposto è il 'diritto paterno', che è il diritto imposto dal 'padre signore della guerra' su cui si 'deve' soltanto giurare (ius iurandum). La coniutario dei fratelli non è contro il padre, o um sovrano, un tirano, o um nemico, ma è per una convivenza condivisa, libera dalla sovranità e dall'inimicizia. Esso è giurato insieme, ma non è prodotto di uma congiura."

73. RESTA (2005) p. 132, tradução nossa. “b) Per questo è libero dall'ossessione dell'identità che dovrebbe legittimarlo. È lontano de um ethnos che lo giustifichi, ma pronto a constituire un demos grazie ad un patto. La sua 'radice errante' trova il suo terreno in um spazio politico aperto, privo di quel território che, più o meno artificialmente, ne giustifica il domínio. Non chiede altre giustificazioni che la com-munitas, appunto il compito condiviso." 
Essa liberdade do Direito Fraterno em relação às identidades não se confunde com a de assimilação, mas sim com a ideia de aceitar as diferenças, pois elas servem para complementar a humanidade e não para isolá-la. Acrescendo ao supracitado, Resta apresenta, no terceiro pressuposto, que a humanidade é o lugar em que os direitos humanos podem ser ameaçados ou tutelados, ou seja, as ações dentro da humanidade é que determinam os resultados de acolhida ou de repulsa, de amizade ou inimizade, sempre revelando o paradoxo existente na sociedade.

c) O seu olhar voltado além dos limites, em direção às proximidades distantes, pede revogação da decisão do "direito de cidadania" que é sempre lugar de exclusão através de um ethnos. Para isso a sua forma é aquela dos direitos humanos, mas um pacto em que eles estão vazios de metafísica e livres de uma retórica somente consolatória. O olhar vai à humanidade como um "lugar comum" e não como abstração que confunde tudo e mascara as diferenças. Os direitos humanos têm uma dimensão "ecológica", são o espaço no qual as duplas contrastantes vêm a serem inclusas: isto leva à consciência que os direitos humanos podem ser ameaçados somente na humanidade, mas podem ser tutelados sempre e somente na mesma humanidade; não por uma natureza, um Deus, um terceiro, qualquer outra abstração metafísica, mas pelos homens de carne e osso, por nós na vida cotidiana ${ }^{74}$.

74. RESTA (2005) p. 132, tradução nossa.“c) Il suo sguardo rivolto oltre il confine, verso prossimità lontane, richiede revoche decise di quel 'diritto di cittadinanza' que è da sempre luogo dell'esclusione attraverso un ethnos. Per questo la sua forma è quella dei diritti umani, ma a patto che essi siano svuolati della metafisica e liberi de una retorica soltanto consolatória. Lo sguardo va all'umanità come un 'luogo comune' e non come l'astrazione che confonde tutto e maschera le differenze. I diritti umani hanno uma dimensione 'ecologica', sono lo spazio nel qual ele copie oppositive vengono ad essere ricomprese: ciò porta alla consapevolezza che i diritti umani possono essere minacciati soltanto dall'umanità stessa; non da uma natura, um Dio, um Terzo, una qualsiasi altra astrazione metafisica, ma dagli uomini in carne ed ossa, da noi nella vita quotidiana." 
No artigo $4^{\circ}$ da Nova Lei de Migrações, consta a disposição de que, ao migrante que esteja no Brasil, são garantidos os direitos em igualdade com os nacionais, bem como serão aplicados deveres em conformidade com a legislação brasileira ${ }^{75}$. Dentre os direitos apresentados, citam-se os direitos e liberdades civis, sociais, culturais e econômicos (I); direito de transferir recursos decorrentes de sua renda e economias pessoais a outro país, observada a legislação aplicável (V); direito de associação, inclusive sindical, para fins lícitos (VII), direito do imigrante de ser informado sobre as garantias que lhe são asseguradas para fins de regularização migratória (XVI), dentre outros. A percepção de que tanto migrantes quanto brasileiros têm seus direitos humanos assegurados relaciona-se com o quarto pressuposto do Direito Fraterno. Importante observar que o pressuposto número quatro está diretamente ligado ao pressuposto de número um, no qual Resta apresenta a importância do compartilhamento de responsabilidades, pois os direitos humanos são o lugar das responsabilidades e não das delegações.

75. BRASIL (2017). Art. 4o Ao migrante é garantida no território nacional, em condição de igualdade com os nacionais, a inviolabilidade do direito à vida, à liberdade, à igualdade, à segurança e à propriedade, bem como são assegurados: I- direitos e liberdades civis, sociais, culturais e econômicos; II- direito à liberdade de circulação em território nacional; III- direito à reunião familiar do migrante com seu cônjuge ou companheiro e seus filhos, familiares e dependentes; IV- medidas de proteção a vítimas e testemunhas de crimes e de violações de direitos; V- direito de transferir recursos decorrentes de sua renda e economias pessoais a outro país, observada a legislação aplicável; VI- direito de reunião para fins pacíficos; VII- direito de associação, inclusive sindical, para fins lícitos; VIII- acesso a serviços públicos de saúde e de assistência social e à previdência social, nos termos da lei, sem discriminação em razão da nacionalidade e da condição migratória; IX- amplo acesso à justiça e à assistência jurídica integral gratuita aos que comprovarem insuficiência de recursos; X- direito à educação pública, vedada a discriminação em razão da nacionalidade e da condição migratória; XI- garantia de cumprimento de obrigações legais e contratuais trabalhistas e de aplicação das normas de proteção ao trabalhador, sem discriminação em razão da nacionalidade e da condição migratória; XII- isenção das taxas de que trata esta Lei, mediante declaração de hipos suficiência econômica, na forma de regulamento; XIII- direito de acesso à informação e garantia de confidencialidade quanto aos dados pessoais do migrante, nos termos da Lei № 12.527 , de 18 de novembro de 2011; XIV- direito a abertura de conta bancária; XV- direito de sair, de permanecer e de reingressar em território nacional, mesmo enquanto pendente pedido de autorização de residência, de prorrogação de estada ou de transformação de visto em autorização de residência; e XVI- direito do imigrante de ser informado sobre as garantias que lhe são asseguradas para fins de regularização migratória. 
d) A consciência da distância entre ser humano e ter humanidade sugere ao Direito Fraterno uma antropologia dos deveres que corresponde, à S. Weil, à gramática dos direitos. Removido da metafísica, os direitos humanos são o lugar da responsabilidade e não da delegação; esses constituem a crítica mais forte da tolerância, daquela prática, embora virtuosa, que confirma e se alimenta de todas as dissimetrias; por isso eles pedem a revogação mais decisiva de todos os etnocentrismos. Por isso o direito fraterno é cosmopo$\operatorname{lita}^{76}$.

Pertencer à humanidade não significa, necessariamente, ter humanidade, no sentido de ser fraterno para com o outro. Por causa dessa ausência de fraternidade é que se presenciam tantos conflitos que geram crises econômicas, sociais e perseguições. Ser humano, no sentido de ter humanidade, como Resta menciona, é reconhecer os direitos acima elencados aos migrantes. Arendt advoga que o paradoxo da perda dos direitos humanos é a transformação da pessoa em um humano somente, sem especificações (profissão, cidadania, opinião), o que faz com que se perca seu significado por ser individual, singular. Assim, por pertencerem a outra comunidade, esse "estrangeiro" só tem participação política e possibilidade de diálogo na sua comunidade ${ }^{77}$.

Partindo da necessidade de participação na sociedade, no segundo capítulo da Lei, apresenta-se a situação documental do migrante, dispondo sobre os documentos de viagem (artigo $5^{\circ}$ ) e os vistos (artigos $6^{\circ}$ ao 22 ). No capítulo terceiro da Lei, discorrese a respeito das condições do migrante, como o residente fronteiriço (artigo 23), o apátrida (artigo 26) e o asilado (artigo 27). Toda essa regularização é o resultado do reconhecimento de diversos tipos de migração que ocorrem na atualidade e que necessitam de atenção e políticas próprias, conforme suas especificidades (descritas no artigo $2^{\circ}$ da Lei e nas Portarias Interministeriais). Tais disposições relacionam-se à busca do Direito Fraterno em destituir o código amigo/ inimigo, nos termos do quinto pressuposto:

\footnotetext{
76. RESTA (2005) p. 132, tradução nossa. "d) La consapevolezza della distanza tra essere uomini e avere umanità suggerisce al diritto fraterno um'antropologia dei doveri che corrisponde, alla $\mathrm{S}$. Weil, alla grammatica dei diritti. Scrostati della metafisica, i diritti umani sono il luogo della responsabilità e non della delega; essi constituiscono la critica più forte della 'toleranza', di quella pratica, pur virtuosa, che conferma e si alimenta di tutte le disimmetrie; perciò essi chiedono la revoca più decisa di tutti gli etnocentrismi. Per questo il diritto fraterno è cosmopolita".
}

77. ARENDT (1998) pp. 335-336. 
e) Destituindo o jogo do amigo-inimigo, o direito fraterno é não violento. Não incorpora a ideia do inimigo sob outra forma, e por isso é diferente em relação à guerra. É, se dizia, jurado em conjunto, mas não produto daquela trama que leva simbolicamente à "decapitação do rei” e que, nota-se, leva nas costas o sentimento de culpa que sobrevive ao jogo "sacrifical" de qualquer democracia. Por isso, não pode defender os direitos humanos enquanto os está violando; a possibilidade da sua existência está toda em evitar o curto-circuito da ambivalência mimética (típica do pharmakon), que o transforma de remédio em doença, de antídoto em veneno. Deixa aberta a estrada à mediação (mediazione) antes de chegar ao juiz que diga a última palavra. A minimização da violência leva a uma ideia de jurisdição mínima, não máxima, e é uma tentativa de resposta àquela "tribunalização da história" que o Ocidente está atravessando ${ }^{78}$.

Nesse rol de direitos, merece atenção o artigo 30 da Nova Lei, no qual estão elencadas as hipóteses de autorização de residência do migrante no Brasil. A autorização de residência permitirá ao migrante a obtenção da Carteira de Registro Nacional Migratório (CRNM), antigo Registro Nacional de Estrangeiro (RNE), que era regulado pelo Estatuto do Estrangeiro.

\footnotetext{
78. RESTA (2005) p. 133, tradução nossa. "Destituendo il gioco d'amico-nemico, il diritto fraterno è non violento. Non incorpora l'idea del nemico sotto altra forma, e per questo è differenza rispetto alla guerra. È, si diceva, giurato insieme, ma non prodotto di quella congiura che porta simbolicamente alla 'decapitazione del re' e che è noto, si porta dietro sensi di colpa che sopravvivono al gioco 'sacrificale' di qualsiasi democrazia. Per questo non può difendere i diritti umani mentre li sta violando; la possibilità della sua esistenza sta tutta nell'evitare il cortocircuito dell'ambivalenza mimética (típica del pharmakon), che lo transforma da rimedio in malattia, da antidoto in veleno. Lascia aperta la strada alla medi-azione prima di arrivareal giudice che dica l'última parola. La minimizzazione della violenza porta ad um'idea di giurisdizione mínima, non massima, ed è un tentativo di risposta a quella 'tribunalizzazione della storia' che l'Ocidente sta attraversando."
} 
I- a residência tenha como finalidade:
a) pesquisa, ensino ou extensão acadêmica;
b) tratamento de saúde;
c) acolhida humanitária;
d) estudo;
e) trabalho;
f) férias-trabalho;
g) prática de atividade religiosa ou serviço voluntário;
h) realização de investimento ou de atividade com relevância econômica, so- cial, científica, tecnológica ou cultural;
i) reunião familiar;

II- a pessoa:

a) seja beneficiária de tratado em matéria de residência e livre circulação;

b) seja detentora de oferta de trabalho;

c) já tenha possuído a nacionalidade brasileira e não deseje ou não reúna os requisitos para readquiri-la;

d) (VETADO);

e) seja beneficiária de refúgio, de asilo ou de proteção ao apátrida;

f) seja menor nacional de outro país ou apátrida, desacompanhado ou abandonado, que se encontre nas fronteiras brasileiras ou em território nacional;

g) tenha sido vítima de tráfico de pessoas, de trabalho escravo ou de violação de direito agravada por sua condição migratória;

h) esteja em liberdade provisória ou em cumprimento de pena no Brasil;

III- outras hipóteses definidas em regulamento ${ }^{79}$.

O pertencer à humanidade também diz respeito ao fato de possuir sua identificação, que é um direito de todo ser humano, para que possa compartilhar dos espaços públicos e ter sua voz ouvida. Como estudado nos tópicos anteriores, embora com as mudanças provenientes da internacionalização dos direitos humanos, o Estado ainda tem autonomia para decidir quem pode entrar em seu território. "Desta forma, cada um dos Estados controla a sua imigração, dentro do domínio de sua soberania, permitindo ou negando acesso ao seu território." ${ }^{\circ 0}$ Nesse sentido, o Direito Fraterno é contra os poderes, conforme o pressuposto de número seis: "f) É então contra os po-

79. BRASIL (2017).

80. COSTA y REUSCH (2016) p. 282. 
deres, de todos os tipos, de uma maioria, de um Estado, de um governo, que, se sabe, exerce o domínio sobre a vida nua." ${ }^{81}$ Ser contra os poderes não significa ser contra a formação do Estado ou qualquer autoridade constituída atualmente, mas sim, contra a ideia de uma maioria que pense e aja pelas minorias.

A Lei No 13.445 de 2017 trouxe muitos benefícios para a realidade migratória brasileira. Inovou em muitos aspectos e, como já mencionado anteriormente, o principal é o fato de retirar do tema das migrações o viés de segurança nacional que permeava todo o Estatuto do Estrangeiro. Mesmo assim, a Nova Lei tem a necessidade de apresentar disposições sobre a entrada e a saída do território nacional (artigos 38 ao 60) e, na sequência, medidas de cooperação, como a extradição (artigos 81 ao 105), enfatizando, contudo, a preservação dos direitos humanos, como se pode ver na seção $\mathrm{V}$ que veda as seguintes medidas:

Art. 61. Não se procederá à repatriação, à deportação ou à expulsão coletivas.Parágrafo único. Entende-se por repatriação, deportação ou expulsão coletiva aquela que não individualiza a situação migratória irregular de cada pessoa.

Art. 62. Não se procederá à repatriação, à deportação ou à expulsão de nenhum indivíduo quando subsistirem razões para acreditar que a medida poderá colocar em risco a vida ou a integridade pessoal ${ }^{82}$.

Ainda, a Nova Lei apresenta as disposições sobre nacionalidade e naturalização (artigos 63 ao 76), pois, embora se busque um código fraterno, em que todos reconheçam-se de forma igual, o mundo ainda é formado por Estados soberanos que ditam as suas regras sobre nacionalidade e cidadania. Talvez, aqui, encontre-se um dos paradoxos do estudo das migrações e da fraternidade, pois, ao mesmo tempo em que as legislações caminham em direção à maior tutela dos direitos humanos, ainda estão sob o manto de uma nação soberana. Como observam Wermuth e Dezordi, "a cidadania se subordinou à nacionalidade e os direitos garantidos por ela, foram destinados aos nacionais, excluindo-se os 'inimigos', ou seja, os de fora, os que pertencem à indiferenciação da communitas." ${ }^{83}$

81. RESTA (2005) p. 133, tradução nossa. "È dunque contro i poteri, di tutti i tipi, di una maggioranza, di uno Stato, di un governo, che, si as, essercitano il domínio sulla 'nuda vita.'

82. BRASIL (2017).

83. WERMUTH y DEZORDI (2017) p. 309. 
Convém ressaltar, também, a preocupação da Nova Lei de Migrações com os emigrantes, os brasileiros que deixam o Brasil para viver no exterior (artigos 77 ao 80), que também necessitam de acolhimento, seja pela tutela brasileira no exterior, seja pela cooperação com outras nações. Nesse sentido, essa ideia de acolhimento e pertencimento é abordada no sétimo pressuposto:

g) O direito fraterno é inclusivo, no sentido que escolhe direitos fundamentais e define o acesso universalmente compartilhado a bens inclusivos. Bens e direitos fundamentais são inclusivos quando um indivíduo não pode usufruir deles se no mesmo momento nenhum outro indivíduo pode usufruir. $\mathrm{O}$ ar, a vida, o patrimônio genético não podem ser senão inclusivos; podem ser ao menos propriedade quando não são igualmente distribuídos ${ }^{84}$.

Para finalizar, no oitavo pressuposto, Resta sintetiza todas as bases transdisciplinares que formam o Direito Fraterno e apresenta a aposta na fraternidade:

h) É a aposta de uma diferença em relação aos outros códigos que guardam a diferença entre amigo e inimigo; nisso é particularmente instrutivo o modelo kantiano de Menschenfreund que Freud e Einstein reinterpretam no seu debate dos anos trinta sobre a guerra ${ }^{85}$.

A fraternidade, então, é a aposta em um mundo sem muros, sem fronteiras, sem distinções de nacionalidade que causam as divisões de amigos/inimigos e a diferenciação de quem é interno e quem é externo. Por meio do Direito Fraterno busca-se desviar o olhar dessas identidades utilizadas para diferenciar as pessoas, busca-se algo além disso, enxerga-se somente um humano que, por pertencer a mesma humanidade, é detentor de direitos. Migrantes ou não, todos são humanos. A Nova Lei de Migrações, embora ainda pautada pela soberania estatal brasileira, é o primeiro passo para o reconhecimento de que há algo acima da nacionalidade. A temática das migrações apresenta limites e possibilidades que merecem ser trabalhados em conjunto

84. RESTA (2005) p. 133, tradução nossa."Il diritto fraterno è inclusivo, nel senso che sceglie diritti fondamentali e definisce l'acesso universalmente condiviso a beni 'inclusivi'. Beni e diritti fondamentali sono inclusivi quando un individuo non può goderne se nello stesso momento non ne godono tutti gli altri. L'aria, la vita, il patrimônio genético non possono che essere inclusivi; possono esserlo meno le proprietà quando non ono ugualmente distribuite."

85. RESTA (2005) p. 133, tradução nossa. "È la scommess di uma differenza rispetto agli altri codici che guardano alla differenza tra amico e nemico; in questo è particolarmente istruttivo il modelo kantiano di Menschenfreud che Freud e Einstein rileggono nel loro dibattito degli anni Trenta sulla guerra." 
pela sociedade civil, pelos governos e pelos migrantes para que, cada vez mais, a sociedade brasileira seja inclusiva. Apostar então na fraternidade, é apostar na migração e em um mundo melhor.

\section{Considerações finais}

\section{"[...] convém, então, apostar na fraternidade."}

O presente estudo abordou a temática migratória por meio do Direito Fraterno, desenvolvido na Metateoria do Direito Fraterno de Eligio Resta. Analisou-se a Nova Lei de Migrações brasileira, Lei $\mathrm{N}^{\circ} \mathbf{1 3 . 4 4 5}$, de 24 de maio de 2017 , e os aspectos da fraternidade existentes em suas disposições. A importância do estudo das migrações reside no fato de que essas são constantes na história da humanidade e que, diante da sociedade globalizada que se tem atualmente, os fluxos migratórios possuem características diversificadas, que requerem olhares transdisciplinares para que as adequadas políticas sejam criadas.

Diante disso, mostra-se importante desenvolver uma pesquisa acerca dos fluxos migratórios sob a perspectivas de novas teorias, como o Direito Fraterno, que aborda a questão dos paradoxos da sociedade complexa e do reconhecimento do outro como o outro-eu. A fraternidade, embora fizesse parte do lema da Revolução Francesa, foi esquecida, deixando um vazio entre a liberdade e a igualdade. Retorna, anacronicamente, como uma forma de inclusão, de pertencimento de todos à humanidade. Esse pertencimento se justifica por meio de uma civitas maxima.

Já se reconhece, com a internacionalização dos direitos humanos, um direito de migrar, contudo, não se reconhece um dever de acolhida dessas pessoas em deslocamento. As nações, ao mesmo tempo em que tutelam direitos humanos em legislações, sentem-se ameaçadas pela presença daqueles que vêm de fora, além de suas fronteiras. O Direito Fraterno é a aposta no rompimento entre humanidade, cidadania e nacionalidade. O paradoxo ainda existente na sociedade é a divisão do mundo em Estados soberanos, que delimitam suas fronteiras. Assim, a fraternidade retornou, anacronicamente, para desvelar esses paradoxos.

Devem ser observados os limites e as possibilidades na sociedade formada por migrantes e nacionais. As diferenças devem complementar as comunidades, criar novos laços, novas trocas. A publicação da Nova Lei de Migrações no Brasil apresenta a mudança de uma visão do migrante voltada para a segurança nacional, para uma visão dos direitos humanos, apresentando, assim, ideias que vão ao encontro do Dire-

86. RESTA (2005) p. 133, tradução nossa. “[...] conviene, dunque, scommettere sulla fraternità.” 
ito Fraterno. Diante do exposto, observa-se que o Brasil evoluiu muito em questão de política e legislação migratória e cabe, agora, à sociedade, aos governantes e aos próprios migrantes criarem as demandas e fiscalizarem a correta aplicação das normas, para que os direitos sejam efetivados.

Neste artigo, foram apresentadas faíscas de uma ideia incandescente na sociedade complexa, de busca por uma civitas maxima, como visto na Metateoria do Direito Fraterno, em que pese a divisão da ordem internacional formada por Estados soberanos. Deve-se apostar, agora, em concretizações da fraternidade para que seja uma forma de acolher e desenvolver a vida dos migrantes. O Direito Fraterno pode ser a aposta em um mundo em que todos pertencem a uma identidade maior, que é a própria humanidade.

\section{Referências bibliográficas}

ACNUR (2018). “Tendencias globales: desplazamientos forzado em 2017. Disponible en: https://s3.amazonaws.com/unhcrsharedmedia/2018/Global_Trends_Forced_ Displacement_in_2017/TendenciasGlobales_2017_web.pdf. [Fecha de consulta: 20 de julio de 2018].

ARENDT, Hannah (1998): Origens do totalitarismo (São Paulo, Companhia das Letras).

ARNAUD, André-Jean (200o): Dicionário enciclopédico de teoria e de sociologia do direito (Rio de Janeiro, Renovar, 2ed.).

BAGGIO, Antonio Maria (2013): "The forgotten principle: fraternity in its public dimension. Claritas Journal of Dialogue and Culture". En West Lafayette, v. 2, $\mathrm{N}^{\circ}$ 2, octubre de 2013, pp.35-52. Disponible en https://docs.lib.purdue. edu/cgi/ viewcontent.cgi? article $=1052 \&$ context $=$ claritas. $[$ Fecha de consulta:13 de julio de 2018].

BRASIL (2017): "Lei No 13.445, de 24 de maio de 2017". Disponible en www. planalto.gov.br/ccivil_03/_Ato2015-2018/2017/Lei/L13445.htm. [Fecha de consulta: 31 de agosto de 2018].

BRASIL (1998). “Constituição da República Federativa do Brasil de 1988.” Disponible en www.planalto.gov.br/ccivil_03/constituicao/constituicaocompilado.htm. [Fecha de consulta: 31 de agosto de 2018].

COSTA, Marli Marlene da y Reusch, Patricia Thomas (2016). "Migrações internacionais (soberania, direitos humanos e cidadania)." En Passagens: Revista internacional de história política e cultura jurídica, Rio de Janeiro, v. 8, n. 2, mayo-agosto de 2016, pp. 275-292. Disponible en www.revistapassagens.uff.br/index.php/ Passagens/article/view/99. [Fecha de consulta: 31 de agosto de 2018]. 
GUERRA, Sidney (2017): Direitos humanos: curso elementar (São Paulo, Saraiva).

JUBILUT, Liliana Lyra (2007): O direito internacional dos refugiados e sua aplicação no ordenamento jurídico brasileiro. (São Paulo, Método).

LISOWSKI, Telma Rocha (2012). "A apatridia e o "direito a ter direitos": um estudo sobre o histórico e o estatuto jurídico dos apátridas." En Revista Jurídica da Procuradoria Geral do Estado do Paraná, Curitiba, No 3, pp. 109-134. Disponible en www.pge.pr.gov.br/arquivos/File/Revista_PGE_2012/ Artigo_4_A_Apatridia. pdf. [Fecha de consulta: 22 de julio de 2018].

MACHADO, Carlos Augusto Alcântara (2015). "Constitucionalismo fraternal”. En Revista Diálogos Possíveis, Salvador, v. 14, No 2, julio/diciembre, pp. 3-19. Disponible en http://revistas.faculdadesocial.edu.br/index.php/dialogospossiveis/article/ view/307/241. [Fecha de consulta: 22 de julio de 2018].

MAZZUOLI, Valério de Oliveira (2014): Curso de direitos humanos (São Paulo, Método).

MINISTÉRIO DA JUSTIÇA (2018). “Refúgio em números.” Disponible em file://C:/ Users/ User/Downloads/REF\%C3\%9AGIO\%2oEM\%2oN\%C3\%9AMEROS_1104. pdf. [Fecha de consulta: 22 de julio de 2018].

RAMOS, André de Carvalho et al (2017). "Regulamento da nova Lei de Migração é contra legem e praeter legem." En O Consultor Jurídico. [online] de 23 noviembre de 2017. Disponible en www.conjur.com.br/2017-nov-23/ opiniao-regulamento-lei-migracao-praetem-legem. [Fecha de consulta: 22 de julio de 2018].

REIS, Rossana Rocha (2004). "Soberania, direitos humanos e migrações internacionais." En RBCS, São Paulo, v. 19, No 55, junio, pp. 149-164. Disponible en www.scielo.br/pdf/rbcsoc/v19n55/ao9v1955.pdf $>$. [Fecha de consulta: 22 de julio de 2018].

RESTA, Eligio (2005): Il diritto fraterno. (Roma, Laterza).

RESTA, Eligio (2004): O direito fraterno (traducción de MARTINI, Sandra Regina), (Santa Cruz do Sul, Editora da UNISC).

RESTA, Eligio (2015). "La vita nelle forme. Tra diritto ed estetica." En Dossie La vita nelle forme. Il diritto e le altre arti, Urbino, v. 8, pp. 17-22. Disponible en http:// amsacta.unibo.it/5561/1/2015_ISLL_Dossier\%2OAtti_Urbino_2014.pdf. [Fecha de consulta: 22 de julio de 2018].

RESTA, Eligio et al. (2017). "Direito e fraternidade: a dignidade humana como fundamento." En Revista do Direito, Santa Cruz do Sul, v. 3, No 53, diciembre, pp. 92-103. Disponible en https://online.unisc.br/seer/index.php/direito/ article/ view/11364/6967. [Fecha de consulta: 22 de julio de 2018]. 
STURZA, Janaína Machado y BRANDt, Daiana (2016). "O direito e a sociedade contemporânea: interlocuções com o direito fraterno." En MARTINI, Sandra Regina y MAIA, Selmar José (Org.). O movimento entrevv os saberes: a transdisciplinaridade e o direito (Porto Alegre, Evangraf, v. 2), pp. 123-133.

VENTURA, Deisy (2015). "Mobilidade humana e saúde global." En Revista USP, São Paulo, No 107, outubre/ noviembre/diciembre de 2015, pp. 55-64. Disponible en www.revistas.usp.br/revusp/article/view/115113. [Fecha de consulta: 22 de agosto de 2018].

VENTURA, Deisy (2017). "Prefácio." En DUTRA, Cristiane Feldmann y PEREIRA, Gustavo de Lima (Org.). "Direitos humanos e xenofobia: violência internacional no contexto dos imigrantes e refugiados." (Curitiba, Prismas) pp. 5-13.

WERMUTH, Maiquel Angelo Dezordi y NIELSSON, Joice Graciele. "De Hannah Arendt a Judith Butler: em busca da humanidade perdida nas fronteiras do estadonação." En Pensar: Revista de Ciências Jurídicas, Fortaleza, v. 22, № 1, enero/abril, pp. 301-334. Disponible en http://periodicos.unifor.br/rpen/ article/view/4322. [Fecha de consulta: 22 de agosto de 2018]. 